\title{
Sugárkapu-rendszerek fejlesztése Magyarországon
}

A radioaktivitás felfedezése óta megszakítás nélkül használatban vannak az ionizáló sugárzást (továbbiakban: sugárzás) kibocsátó anyagok, eszközök. Ez a technológia mára a mindennapi élet részévé vált, legyen szó orvosi (pl.: fogászati röntgen, nukleáris medicina), vagy ipari (pl.: varratvizsgálat, energiatermelés) alkalmazásról. Nem szabad azonban elfeledkezni a veszélyeiről sem: az ionizáló sugárzás színtelen, szagtalan, a sugárzás minőségétől függően a legtöbb anyagon képes áthatolni, az élő szervezetet károsítja.

$A z$ ionizáló sugárzást kibocsátó anyag (továbbiakban: sugárforrás) szemrevételezéssel felismerhetetlen, a sugárzás azonnali tüneteket csak nagy dózis elszenvedése esetén vált ki, kis dózisok hatása csak évek, évtizedek múlva okozhat megbetegedést [1]. A védekezés az észleléssel kezdődik, amelyhez nagy biztonsággal tudni kell, hogy az adott ponton található-e valamilyen sugárforrás. Ennek meghatározása kizárólag műszerek segítségével lehetséges. A sugárkapuk olyan sugárzásra érzékeny berendezések, amelyek lehetővé teszik rejtett sugárforrások, valamint radioaktív szennyeződések detektálását. Ezen rendszerek jelentőségét mutatja pl., hogy egy liternyi térfogatú uránt - ami már atombombaként használható [2] - könnyen el lehet rejteni egy jármüben úgy, hogy az a szokásos vizsgálatoknál alkalmazott eszközökkel nem mutatható ki, kizárólag egy sugárkapu segítségével észlelhető.

Sugárforrások, illetve sugárszennyezettség felderítésére állandó vagy ideiglenes ellenőrzőpontokon - az elmúlt évtizedek gyakorlatának megfelelően - rendszerint folyamatos, autonóm működésre képes, nagy érzékenységű sugárkapu-rendszereket alkalmaznak. A sugárkapuval végzett műszeres vizsgálat során a mérés távolról történik, miközben a vizsgált objektum (jármü, személy, csomag) kontrollált módon elhalad a sugárkapuba szerelt detektor(ok) előtt. Mivel a sugárzást a forrást burkoló csomagolás, illetve bizonyos mértékben a levegő is elnyeli, intenzitása ezáltal csökken, ezért a mérést a forráshoz a lehető legközelebb kell elvégezni, illetve a lehető leghosszabb ideig kell a detektor „látóterében” tartózkodni.

A schengeni határokon keresztül közúton vagy vasúton Magyarországra érkező sugárzó anyagok kiszűrésére létrehozott védelmi rendszer fenntartása jelenleg a Rendőrség hatáskörébe tartozik. A sugárzásszennyezések elleni védekezés a Magyar Honvédség vegyivédelmi alakulatainak egyik alapfeladata. Sugárfelderítéssel kapcsolatos feladatokat látnak el a BM OKF (Belügyminisztérium Országos Katasztrófavédelmi Főigazgatóság) Katasztrófavédelmi Mobil Laborjai (KML, KML-ADR) és Katasztrófavédelmi Sugárfelderítő Egységei (KSE) is.

E tanulmányban a napjainkra már az egész világon, a határvédelem fémhulladék-ellenőrzés katonai feladatainak ellátása során is általánosan használt sugárkapu-rendszerek felépítése, fejlesztése és hazai telepítésének vizsgálata mellett arra is keressük a választ, hogy a rendelkezésre álló új technológiákat beépítve a sugárkapu-alkalmazásokba, hogyan lehet még hatékonyabbá tenni a sugárfelderítést.

\section{A SUGÁRKAPU RÉSZEGYSÉGEI}

Egy sugárkapu-rendszer képességeit a részegységei és azok együttmüködése határozza meg.

A főbb részegységek és azok funkciói a következők:

- A detektoregység feladata a sugárzás érzékelése, riasztásjelzés generálása és a mért adatok továbbítása. Egy detektoregységben több detektor is helyet kaphat. A detektornak a vizsgált tárgy vagy személy irányából érkező sugárzás változásaira kell a lehető legérzékenyebbnek lennie. Az irányfüggés biztosításának egyik módja a detektor ólomárnyékolással történő kollimálása (sugárnyaláb fényoptikailag történő párhuzamosítása) [3]. Amennyiben a detektor a sugárzás szignifikáns növekedését észleli, riasztási jelet küld a riasztóegység felé.
ÖSSZEFOGLALÁS: A magyar fejlesztésú és gyártású sugárkapu-rendszerek már évtizedek óta védik Magyarország határait, hogy engedély nélkül ne kerülhessenek sugárzást kibocsátó anyagok, eszközök az ország területére. A technológia fejlődésével ezek a rendszerek is sokat változtak, hogy megfeIeljenek a mai kor kihívásainak. Jelen tanulmány ismerteti ezen rendszerek fejlődésének történetét, képességeit, múködését, valamint bemutatja a sugárkapuk katonai, katasztrófavédelmi alkalmazási lehetőségeit.

KULCSSZAVAK: sugárkapu, gamma, sugárzás, sugárszennyezés, határellenőrzés, ABV-felderítés

\footnotetext{
* NKE, Katonai Múszaki Doktori Iskola. ORCID: 0000-0001-5417-2690

* NKE, Katonai Műszaki Doktori Iskola. ORCID: 0000-0003-3571-652X
}

ABSTRACT: The radiation portal monitor systems, developed and manufactured in Hungary, have been protecting the borders of Hungary for decades, so that no radioactive material could enter into the European Union without permission. With advanced technologies these systems have also changed during the past years to meet the challenges of today. This publication describes the history, capabilities and operation of these systems, as well as the unique military and disaster management applications where portal monitors can be used.

KEY WORDS: radiation portal monitor, gamma, radiation, radiation contamination, border control, CBRN reconnaissance 


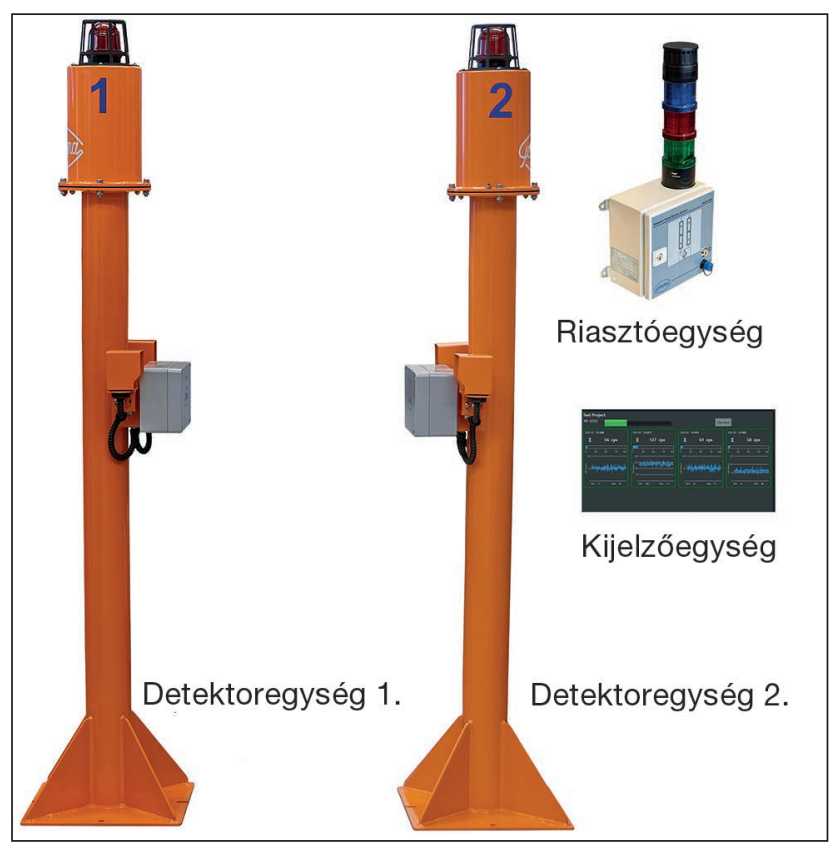

1. ábra. A sugárkapu-rendszer részegységei [3]

- A riasztóegység kezeli a detektoregységeket, riasztás esetén fény- és hangjelzést ad ki, adatokat biztosít a kijelzőegységnek. A riasztást a felhasználó ezen az egységen is észlelheti.

- A kijelzőegység lehetővé teszi a mérési adatok, valamint a teljes sugárkapu aktuális állapotának megjelení- tését, adatok és információk gyűjtését, tárolását, továbbítását.

A kijelzőegység segítségével riasztás esetén a felhasználó könnyebben és pontosabban tudja végrehajtani a megfelelő intézkedéseket. A szoftveres alkalmazás a felhasználó számára megjeleníti a képernyőn, hogy mi a teendő, döntéstámogatást nyújt, kérdéseket tesz fel a kezelőnek és a válaszok értékelését követően megadja a megfelelő utasítást (pl.: más az eljárás, ha a gépjárművezető személy és más, ha maga a jármű bocsát ki sugárzást. Egy fejlett sugárkapu-rendszer képes hatékonyabbá tenni az intézkedést azzal, hogy megadja pl.: azokat a telefonszámokat, amelyeket az operátornak fel kell hívnia. Ha az adott személy nem érhető el, abban az esetben egy eszkalációs listán haladva a rendszer automatikusan felkínálja a következő felelős személy telefonszámát.)

Egy jól konfigurált sugárkapu a mért eredmény függvényében utasítást adhat a jármü körbe kordonozására, megakadályozva ezzel annak megközelítését, vagy a háttérsugárzáshoz közeli riasztás esetén a beavatkozó személynek a rendszer megengedheti, hogy megközelítse a járművet, és további kézi műszeres méréssel keresse meg a sugárzó anyagot.

\section{KIEGÉSZITTŐ KÉPESSÉGEK}

A sugárkapu-rendszerek kiegészíthetők áthaladás-érzékeléssel, video-megfigyeléssel, rendszám-felismeréssel, szállítmány felirat-azonosítással. A rendszer felépítése az alapegységekkel és kiegészítésekkel a 2. ábrán látható. $A z$ adatok alapján, a szállítmányra vonatkozó háttérinformációk

2. ábra. Sugárkapu-rendszer felépítése (a szerzők saját szerkesztése)

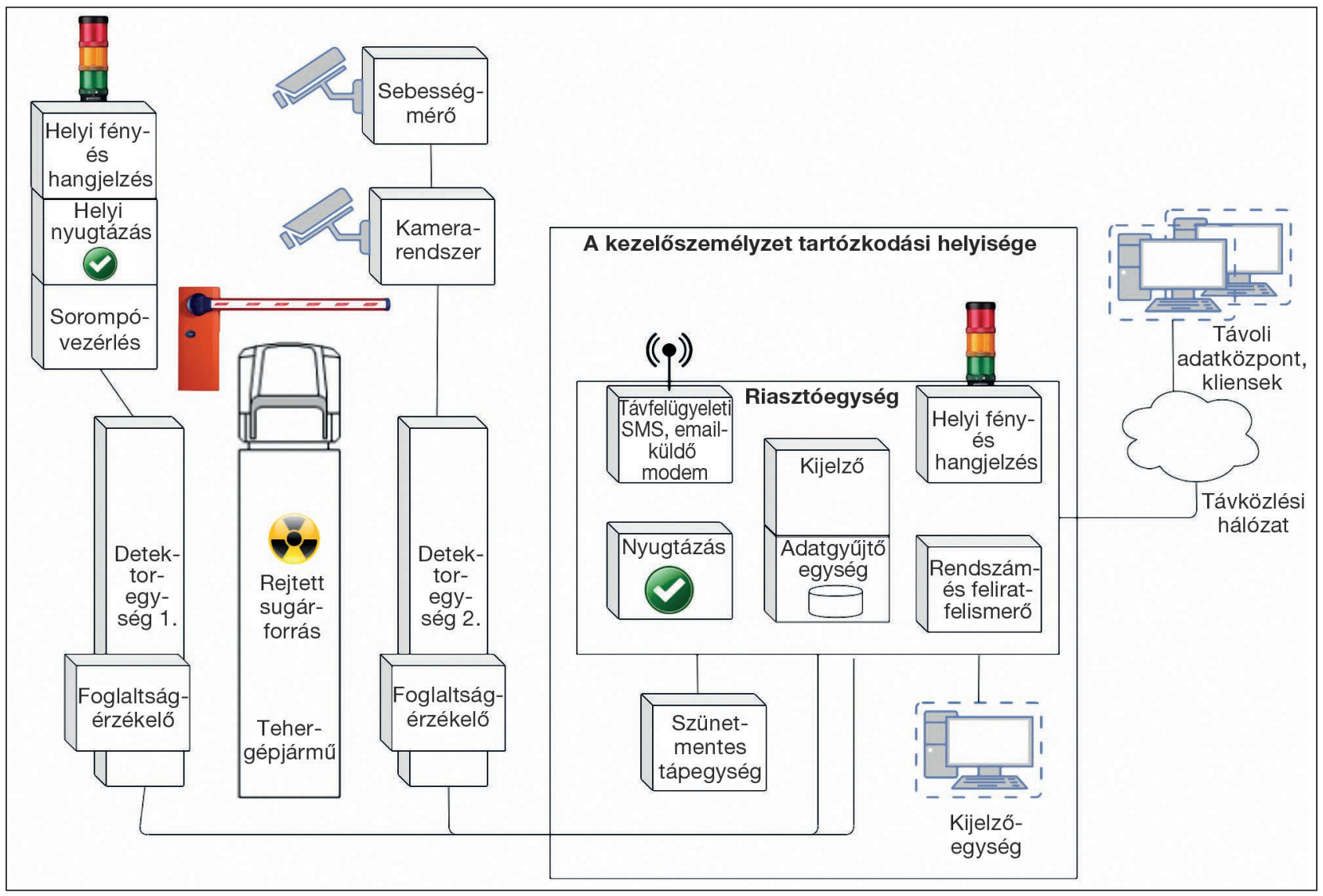


kikereshetők egy adatbázisból. PI.: ADR-szállítmányok esetében kötelező a veszélyes anyagot azonosító felirat elhelyezése a jármű külső felületén [4].

Vonatok esetében a tengelyszámláló meghatározza a szennyeződés elhelyezkedését a szerelvényen belül. Ezzel a technológiával időtakarékos munka végezhető, hiszen egy vonatszerelvény hossza akár $500 \mathrm{~m}$ is lehet. Biztonsági rendszerekkel integrálva, egy adott útszakaszon a sugárkapu engedélyezheti, vagy éppen tilthatja is az áthaladást. A mért adatok, információk egy központba is beérkezhetnek, ezáltal akár több száz ellenőrzési pont is felügyelhetővé válhat egyetlen lokációból.

\section{A SUGÁRKAPU-DETEKTOROK}

A gamma-sugárzás észlelése a sugárkapuk alapképességei közé tartozik. Erre a célra különböző típusú detektorok állnak rendelkezésre. A legegyszerűbbek a gáztöltésű detektorok (ionizációs kamra, proporcionális kamra, GeigerMüller cső). Azonban az ilyen típusú detektorokkal szerelt sugárkapuknak az érzékenysége nem éri el a szcintillációs detektorokkal szerelt sugárkapuk érzékenységét. A szcintillátorok a sugárzást fénnyé alakítják, amely fényt elektromos jellé alakítva meghatározható a sugárszint (dózisteljesítmény) és az energia nagysága. Ezért a sugárkapuknál leggyakrabban a szcintillációs elven működő detektorokat alkalmazzák, azon belül $\mathrm{Nal}(\mathrm{TI})$ vagy plasztik szcintillátorokat.

A plasztik sugárkapu előnye, hogy az ott használt nagy méretű szcintillátor gazdaságosan gyártható, nagy energiájú sugárzások észlelésére optimális, azonban az egységnyi térfogatra jutó fényhozama és spektrális felbontása nem éri el a $\mathrm{Nal}(\mathrm{TI})$ típusú detektor képességeit [5].

További hátrány, hogy a plasztikdetektor irányfüggősége az akár $2 \mathrm{~m}$ széles, több mint $300 \mathrm{~kg}$ tömegü detektor miatt nem megvalósítható. Az irányfüggőség eléréséhez szükséges ólom-kollimálás nem, vagy csak részben alkalmazható a plusz több száz kilogramm tömegnövekedés miatt, így a detektor mögött történő események zavarhatják a mérést.

Alacsony és közepes szintű energiasugárzás észlelésére, valamint szelektív energiamérésekre a Nal(TI) szcintillátorral szerelt detektor a legmegfelelőbb. Ilyen detektorral szerelt sugárkapu látható a 3. ábrán. A Nal(TI) szcintillátoron alapuló teljes rendszer mérete, tömege és ára alapján is előnyösebb, mint egy plasztik szcintillátorokon alapuló

\section{3. ábra. Plasztik és Nal(TI) típusú sugárkapuk [3]}

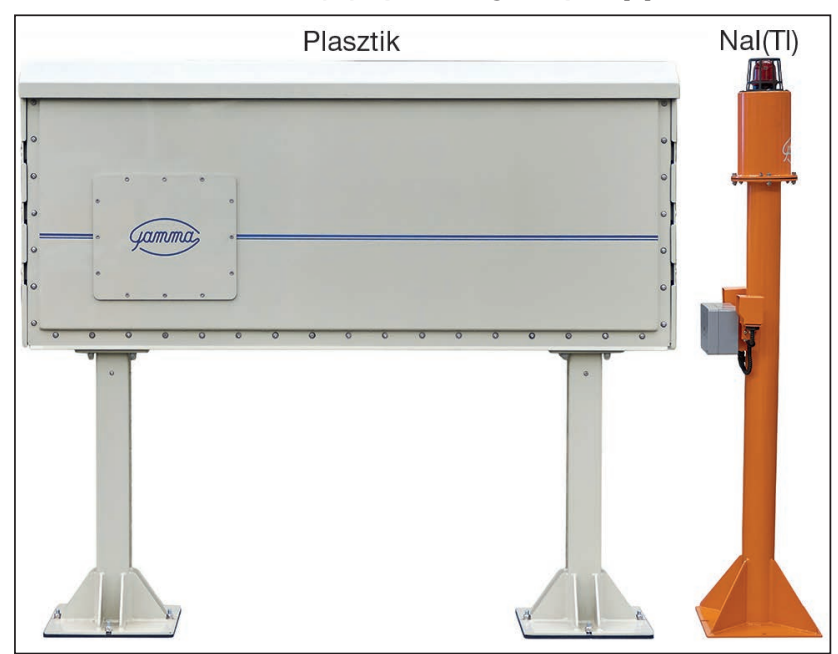

rendszer. A Nal(TI) jó spektrális felbontása lehetővé teszi az izotóp- vagy energiatartomány szelektív azonosítást. Az izotópazonosítási funkció biztosítja a természetes és mesterséges izotópok megkülönböztetését. Az azonosítást néhány másodperc alatt csak nagy sugárszint mellett lehet végrehajtani, ezért a legtöbb esetben az azonosítás folyamata csak akkor indul, ha már megtörtént az elsődleges riasztás. Általában az elsődleges riasztási eseményt követően a feltehetően sugárzó anyagot szállító járművet egy másodlagos ellenőrzési pontra irányítják, ahol az azonosítási eljárás is lefolytatható. Itt már nem elvárás, hogy rövid ideig tartózkodjon az ellenőrzendő jármű az ellenőrzési ponton, így sokkal pontosabb képet lehet kapni a sugárzás eredetéről. Ezzel a másodlagos ellenőrzéssel kiszűrhetők a téves riasztások is.

\section{A NEUTRONSUGÁRZÁs MÉRÉSE}

A gamma-sugárzás mellett a neutronsugárzás mérése is fontos feladat. Erre leggyakrabban He-3 gázzal töltött detektorokat használnak, amelyek szelektíven, nagy érzékenységgel mérik a neutronsugárzást. A Föld légköréből kivonható He-3 készletek kimerülőben vannak, ezért az ára évről-évre egyre magasabb, hamarosan nem lehet majd He-3 gázzal működő detektorokat gyártani. A neutronsugárzás mérhető Bór-plasztik szcintillátor segítségével is, azonban a He-3-nál alacsonyabb érzékenységgel, valamint jelentős gamma-keresztérzékenységgel kell számolni. A keresztérzékenység megszüntetésére megoldás egy kombinált gamma- és neutrondetektor alkalmazása. Többrétegű (szendvics) detektorok alkalmazásával az eltérő hullámhosszú sugárzások más és más rétegekben okoznak fény-(szcintillációs) felvillanást. A fény-felvillanások a detektorban keletkező elektronikus impulzusok az eszköz által mért szélesség alapján szétválaszthatók, így egy detektoron belül meg lehet különböztetni a gamma- és a neutron-sugárzásból érkező jeleket.

\section{A SUGÁRKAPU MÜKÖDÉSE}

A sugárkapu alapfeladata, hogy ha sugárforrás kerül elé, akkor riasztást generáljon. A vizsgálandó jármű/személy legtöbb esetben csak 1-2 másodpercet tölt a kapuban, nincs idő arra, hogy egy távoli számítógépes egység határozzon a riasztásról, ezért a minősítő és döntést hozó algoritmust a sugárkapu detektoregységébe programozták. Ahhoz, hogy a járművek folyamatosan áthaladhassanak a sugárkapun, az ott használt detektornak fél másodpercen belül kell eldöntenie, hogy tovább engedi-e a vizsgált jármúvet/személyt vagy riasztásjelzést vált ki.

A sugárkapu a bekapcsolást követően öndiagnosztikát és egy háttérsugárzás-mérést hajt végre, amihez mérten vizsgálja majd a sugárszint emelkedését. Normál működési módban fél másodpercenként végez el egy mérést, amelynek eredményeit azonnal kiértékeli. Figyelembe veszi, hogy a kapu előtt várakozik-e áthaladásra váró jármü. Amennyiben nincs a háttérhez képest jelentős változás, a detektor a háttérsugárzás értékét automatikusan frissítési, ezáltal képes figyelemmel kísérni a természetes háttérsugárzás ingadozásait.

A mérési eredményeket több időállandóval a következő képlet alapján ellenőrzi az algoritmus:

$M_{i, \tau}>N_{h i, a}+S_{1} \cdot \sqrt{\frac{N_{h i, a}}{\tau}}$, 
ahol

$M_{i, \tau}=$ az átlagos impulzusszám:

$$
M_{i, \tau}=\frac{\sum_{i=1}^{\tau} N_{i}}{\tau} ;
$$

$N_{i}=$ a mérési periódusidő ( 0,5 másodperc) alatt mért impulzusszám;

$\tau=$,időállandó” az átlagolt mérési ciklusok darabszáma;

$N_{h i, a}=$ a háttérsugárzásból adódó beütésszámok átlagértéke:

$$
N_{h i, a}=\frac{\sum_{i=1}^{a} N_{i}}{a} ;
$$

$a=a z$ átlagolt, háttér mérési ciklusok darabszáma;

$S_{1}=$ a kívánt szignifikancia tényezőhöz tartozó szorzófaktor.

Ha az (1) egyenlettel leírt feltétel teljesül, a mérési eredmény szignifikánsan nagyobb a háttérsugárzásnál, a rendszer riasztást generál. Növekvő időállandó, tehát a detektor „látómezejében” töltött idő növekedésével nő a detektor érzékenysége.

A 4. ábrán egy 6 órás periódus során a detektor által mért és képzett értékek impulzus-dimenzióban láthatók.

A 4. ábra jelmagyarázata:

- mérési eredmény: a fél másodperces beütések; (a sor elején piros pontokkal jelölve)

- háttérsugárzás: a kicsúszásmentes impulzusokból képzett csúszó átlag; (a sor elején kék pontokkal jelölve)

- kicsúszás lefelé és fölfelé: az átlagértékből képzett alsó és felső határ, amely a sávon kívüli értéket nem veszi figyelembe az átlagképzés során; (a sor elején zöld pontokkal jelölve)

- foglaltság melletti riasztás: az a háttérből képzett érték, amely felett a rendszer foglaltság mellett riasztást generál; (a sor elején kék jelölés)

- foglaltság mentes riasztás: az a háttérből képzett érték, amely felett a rendszer foglaltság nélkül is riasztást generál.

Téves riasztások szűrhetők ki azzal, hogy a felvett spektrumot egy algoritmus megvizsgálja. A spektrum alapján izotópot azonosít, és ha csak a természetben előforduló izotópot talál, akkor blokkolja a riasztást vagy egy enyhébb fokozatú figyelmeztetést generál. Felmerül a kérdés, hogy tilthatók-e a természetes forrásból származó riasztások? A kezelőszemélyzet munkáját megnehezíti, ha rendszeresen intézkednie kell ártalmatlan (természetes sugárzást kibocsátó) küldemények esetén, ezért sok sugárkapuban

\section{4. ábra. Háttérsugárzás ingadozása, riasztási szintek} változása (a szerzők saját szerkesztése)

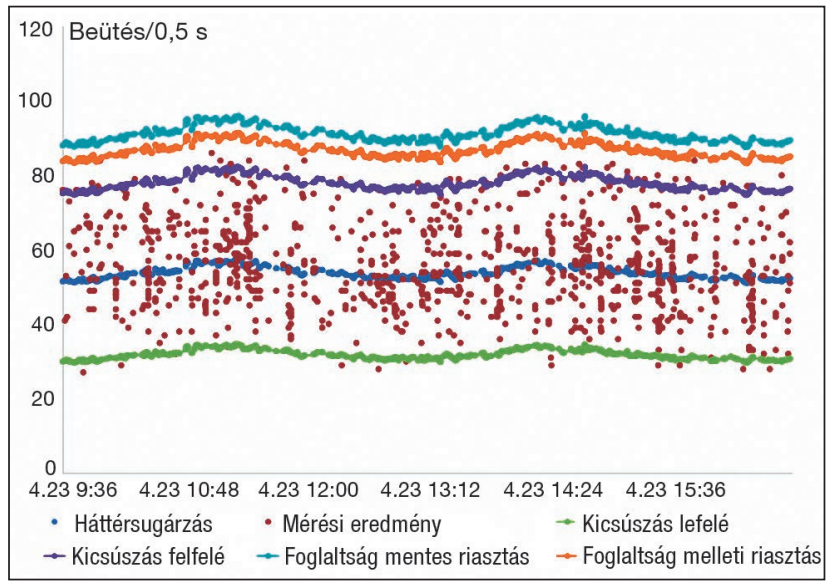

kitiltható a természetes eredetű források okozta riasztás. Azonban ez lehetőséget kínál a csempészeknek arra, hogy a nagy mennyiségű természetes sugárzó anyag mellé veszélyes radioaktív vagy nukleáris anyagokat rejtsenek el.

A rövid mérési idő nem teszi lehetővé, hogy a sugárkapu veszélyes mesterséges forrásból származó kis aktivitásokat észleljen egy nagyobb természetes radioaktív szállítmány mellett, ezért érdemes többszintű ellenőrzési rendszert kiépíteni. A többszintű ellenőrzés első állomása az elsődleges ellenőrzési pont, amelyen sebességkorlátozás mellett halad át a teljes forgalom. Az itt működő sugárkapuk a sugárzó anyag minőségétől, eredetétől függetlenül, határértékszint-átlépés esetén riasztást generálnak. A riasztást kiváltó járművet egy másodlagos ellenőrzési ponthoz irányítják, ahol hosszabb mérési idővel izotóp-azonosítást lehet végrehajtani, amelynek eredménye alapján, a természetes és mesterséges sugárzó anyagok már szétválaszthatók.

Amennyiben a másodlagos sugárkapu mesterséges forrásból származó sugárzást jelez, a szállítmányt meg kell bontani, és kézi sugár-felderítési módszerekkel lokalizálni kell a szennyeződést. A riasztás oka nem csak a szállítmány lehet, előfordul, hogy a gépjármű vezetője kapott korábban olyan orvosi kezelést, ami miatt a teste sugárzást bocsát ki, vagy esetleg a jármű karosszériája szennyezett. A sugárkapu a riasztási jelszint időtartama alapján képes megkülönböztetni pontszerű, illetve kiterjedt szennyeződést. A kiterjedt szennyeződés jelzése általában azt jelenti, hogy a jármű külső felülete szennyeződött, míg a pontszerű jelzés a csomagtérben rejtett sugárforrásra utal.

\section{SUGÁRKAPU-RENDSZEREK MEGJELENÉSE ÉS ELTERJEDÉSE MAGYARORSZÁGON}

Magyarországon elsőként az 1980-ban bekövetkezett csernobili katasztrófát követően merült fel igény a Szovjetunió felől hazánkba belépő szállítmányok sugárszennyezettségének ellenőrzésére. A GAMMA Zrt. (továbbiakban: Gamma) rekord gyorsasággal, 8 nap alatt fejlesztette ki a Polgári Védelem Országos Parancsnoksága kérésére az első „sugárkaput”. A határforgalmat ellenőrző, Gamma által fejlesztett BNS-94 sugárkaput Záhonyban a magyarszovjet (ma: magyar-ukrán) határra telepítették.

Az új eszköz új kihívást, új műszaki megoldásokat igényelt. Olyan, felügyelet nélkül is folyamatos működésre alkalmas mérőrendszerre volt szükség, amely a riasztási szint meghatározásához automatikusan figyelembe veszi a háttérsugárzás pillanatnyi értékét, az áthaladó jármű haladási sebességét, illetve árnyékoló hatását. A Nemzetközi Atomenergia Ügynökség (International Atomic Energy Agency - IAEA) szabályzata a sugárkapuk esetében ma már minimális követelményként írja elő az automatikus háttérkompenzációt és az időállandó korrekciót. A sugárkapuknál alkalmazott automatikus háttérkompenzáció eljárásról 1994. május 20-án nyújtottak be szolgálati szabadalmat. A sugárzásészlelő hálózat bővítése 1997-ben, a Környezetvédelmi Minisztérium finanszírozásában folytatódott. Az európai uniós csatlakozás előkészítése során a Vám- és Pénzügyőrség Országos Parancsnoka, részben uniós (PHARE és EuropeAid) programok keretében tovább bővítette a rendszert, így a 2000-es évek elejére közel 40 mérőrendszert telepítettek Magyarország határállomásaira [6]. Az eredeti szándéknak megfelelően, a rendszert a veszélyes áruk szállítására kijelölt összes határátkelőhelyen, legalább egy közúti vagy vasúti sávon kiépítették. 

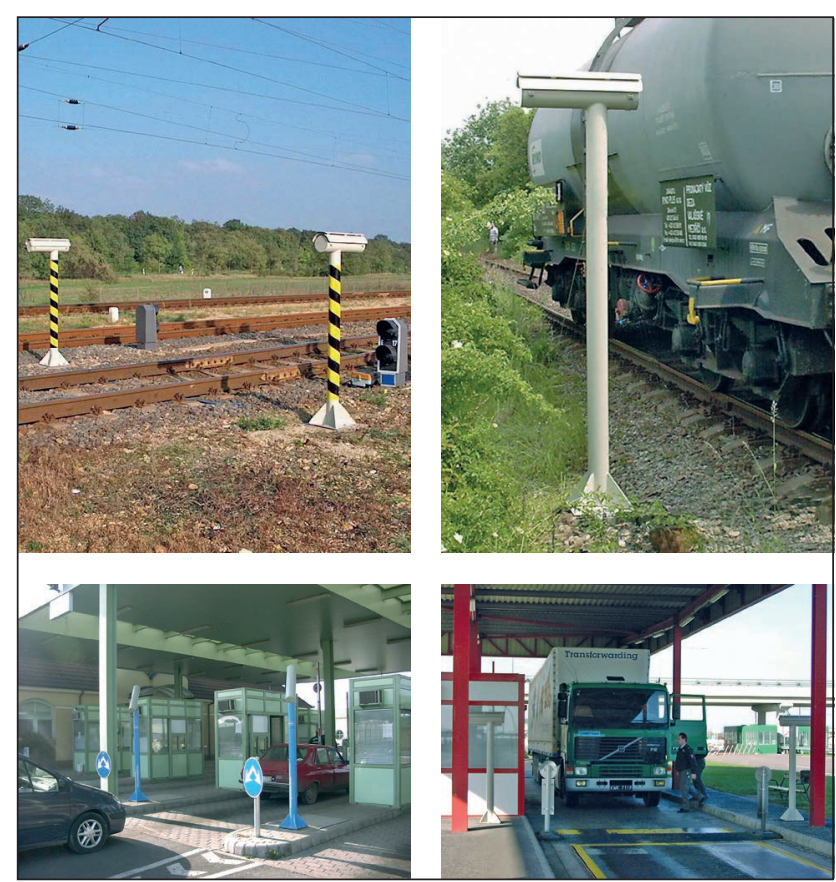

5. ábra. Határállomáson müködő sugárkapuk [3]

Az Európai Unióhoz, valamint a schengeni övezethez történő csatlakozást követően az osztrák, szlovák és szlovén határszakaszokról áttelepítették a sugárkapukat a schengeni határokra. A különböző országok hozzáállására a mai napig jellemző, hogy csupán a szennyező anyagok bejutását kívánják megakadályozni, ezért általában csak az országba érkező szállítmányokat ellenőrzik, a kifelé tartókat nem.

\section{A SUGÁRKAPU-RENDSZEREK ALKALMAZÁSI TERÜLETEI NAPJAINKBAN}

A sugárkapuk kifejlesztését és széleskörű elterjedését elsősorban a csernobili események, majd a Szovjetunió felbomlását követően a nukleáris anyagok csempészésének megakadályozása céljából, a szennyezett anyagokat vagy nukleáris hulladékot tartalmazó jármúvek, közlekedési eszközök szűrésének igénye segítette. Bár fontos feladat volt a határokon áthaladó szállítmányok ellenőrzése, de ez csak az egyik felhasználási lehetőségévé vált a sugárkapuknak. Már a különböző szállítási módok is más és más különböző mű- szaki megoldást igényeltek. A közúti, illetve vasúton történő szállításnál eltérő a rendelkezésre áló vizsgálati eszközökhöz szükséges hely, közúton sem mindegy, hogy kamionok vagy személyautók áthaladását ellenőrzik.

1998 májusában, a spanyolországi Acerinox Fémfeldolgozó Üzemben, véletlenül beolvasztottak egy cézium-137 tartalmú sugárforrást. A levegőbe került radioaktív céziumot Franciaországban, Svájcban, Németországban és Ausztriában is észlelték. A radioaktív szennyezettség okozta károk helyreállítása és a gyártás-kiesés költségei meghaladták a 26 millió USA dollárt [7].

Ez a sajnálatos esemény is rávilágított arra, hogy a radioaktív anyagokkal végrehatott szándékos cselekmények mellett egy véletlen sugárszennyezés is milyen hatalmas károkat okozhat. A sugárkapuk újabb változatainak következő alkalmazói ezért a fémfeldolgozó üzemek lettek. Fémhulladékban igen gyakori a különböző eredetű sugárzó anyagok előfordulása. Ha a radioaktív fém bekerül a kohóba - mint ahogy pl. az két közeli országban is megtörtént [8], a kár milliárdos nagyságrendű is lehet, hiszen a kohót át kell építeni, miközben a termelés kiesése miatt piacvesztéssel is számolni kell. Ezért kezdetben a határállomásokon is alkalmazott berendezéseket, majd később azok speciális feladatra optimalizált változatait kezdték el alkalmazni a fémfeldolgozással foglalkozó vállalatok.

Amennyiben a sugárzó szállítmányról - például az export célokra gyűjtött, külföldi feldolgozásra szánt fém esetén - a határon kifelé menet derül ki, hogy környezetvédelmi szempontból kockázatos, a teljes küldeményt visszafordíthatják, és visszaküldhetik a feladónak. Ennek költsége már egy szállítmány visszafordítása esetén is magasabb lehet egy sugárkapu-rendszer telepítésénél, ezért a határokon és a fémfeldolgozó üzemekben megjelenő mérőrendszereket követően a fémhulladék-gyűjtő telepek is áttértek a sugárkapu-rendszerek alkalmazására. A sugárkapukkal elérték, hogy a telephelyre érkező szállítmányban esetlegesen előforduló szennyezett anyagot kiszűrjék, így az már a telephelyre se juthatott be. Ezzel elkerülhették a szállítmányok későbbi külső központi átvevőhelytől, vagy a határtól való visszafordítását és nem utolsó sorban, így a sugárzás emberre kifejtett hatása ellen is sikeresen tudtak védekezni. A sugárkapuk fémgyűjtőtelepi, illetve kohászati alkalmazása már hazánkban is egyre gyakoribb, erre példák a 6. ábrán láthatók.

A sugárkapuknak a sokféle, akár kommunális hulladékot fogadó lerakókban is szerepe lehet. Ha a depóniára sugárzó anyag kerül, szükségessé válhat az egész telep rekultivációja (újrahasznosításra való alkalmassá tétele) és dekontaminálása (sugármentesítése), ami (nem beszélve a

\section{6. ábra. Sugárkapuk alkalmazása fémhulladék-gyứjtő telepeken [3]}

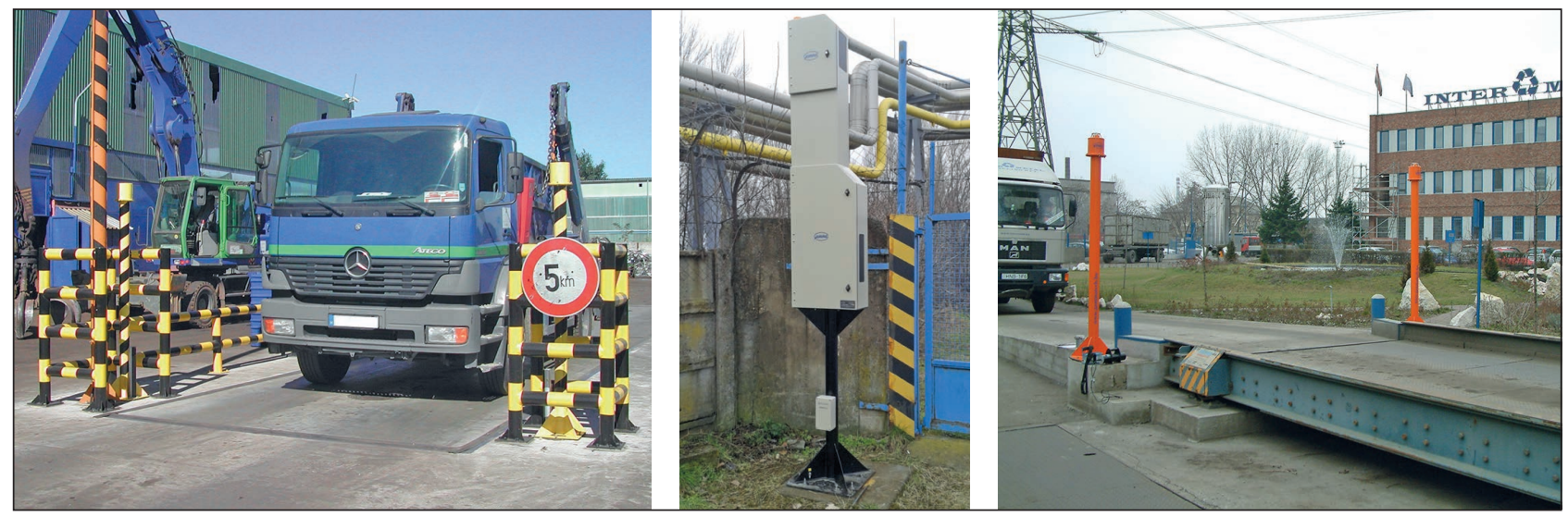




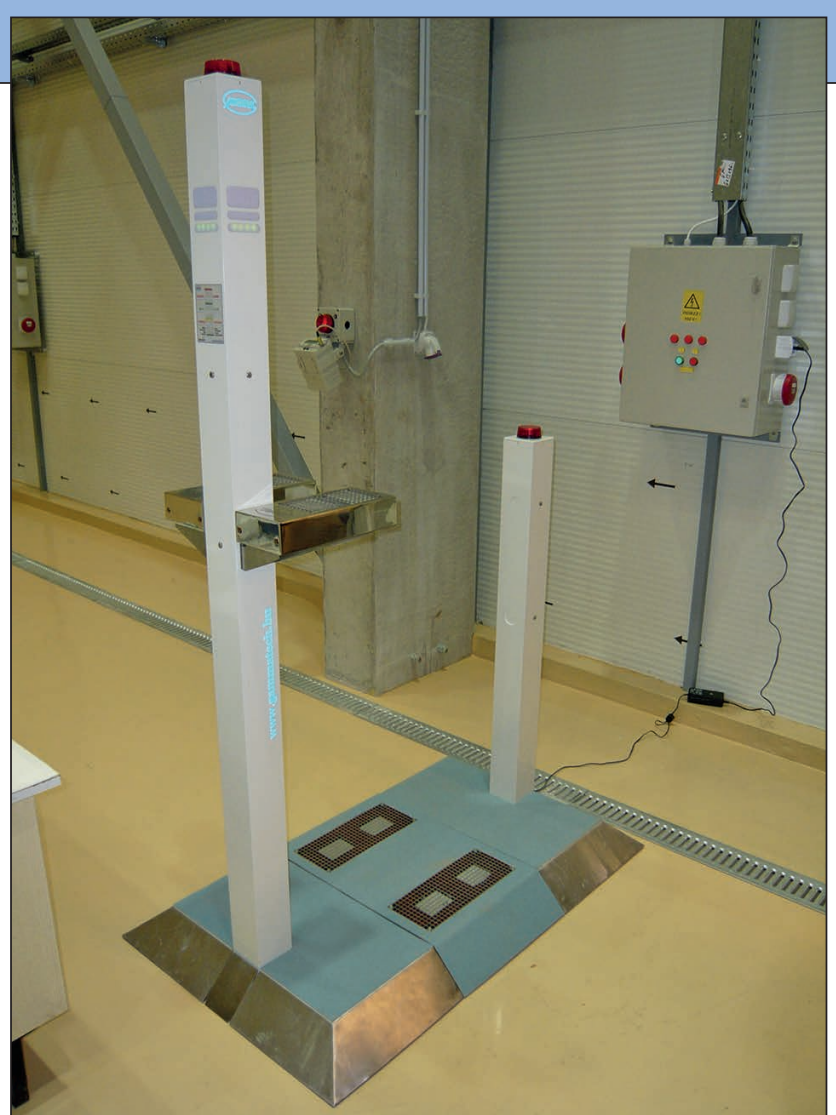

7. ábra. Személyek ellenőrzésére szolgáló fix telepítésű sugárkapuk [3]
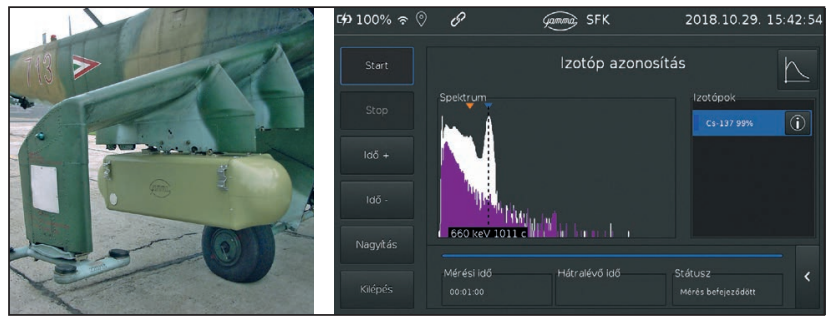

8. ábra. Légi sugárfelderítés és spektrumfelvételek [3]

környezeti károkról), jóval többe kerülhet, mint a detektáló kapuk felszerelése. A magyarországi kommunális lerakók terveiben is szerepelt már ilyen berendezések telepítése, azonban megvalósításra még nem került sor. Magyarországon, ha egy sugárkapu sugárforrást észlel, annak elszállítása és eltemettetése az illetékes hatóság feladata [9].

A sugárkapuk fejlődésével növekedett az érzékenységük, csökkent a méretük és az áruk, és egyre több speciális problémára kínáltak megoldásokat.

Létrejöttek olyan speciális sugárkapuk, amelyek izotóplaboratóriumok, katonai, vagy nukleáris létesítmények be- járatánál elhelyezve alkalmasak a kéz és a láb felületének alfa-, béta-, gamma-szennyezettségének, és a ruházat gamma-szennyezettségének felderítésére.

A Magyarországon kifejlesztett és szabadalmaztatott mérési módszert adaptáló sugárkapuk jelentős fejlesztésen mentek keresztül. Ma már a közúti, vasúti, vízi határátkelőhelyeken, reptereken áthaladó szállítmányok és személyek sugárszennyezettségének azonnali mérésére sugárkapukat alkalmaznak. A gyors ütemü fejlesztést - a saját erőforrások mellett - több esetben segítették a külső támogatók által biztosított források. A jelenleg gyártott sugárkapuk egyik fő alkotóelemének számító intelligens szcintillációs detektor első generációja a Budapesti Kereskedelmi és Iparkamara támogatásával készült el. A Haditechnikai Intézettel történt kutatás-fejlesztési együttműködés keretében, speciális elemként megjelentek a sugárkapukban használt detektorok a légi sugárfelderítésben is, ahol a terep szennyezettségének felderítése mellett elveszett vagy elrejtett pontforrások levegőből történő megtalálására is használják azokat. Egy helikopterre szerelhető változat látható a 8. ábrán.

Az eszköz méretei tovább csökkentek, a kezdetben csak fix telepítésű rendszerek után megjelentek a mobil, vagy mobilizálható berendezések is. Ma már különféle jármüvekbe integrálható mobil sugárkapu-rendszer müködik. Az első felhasználók ezen a téren is az állami cégek voltak. A mobil sugárkapukat a mentesítő rendszereknél a sugárszennyezett területekről érkező szállítmányok, emberek vagy autók gyors ellenőrzésére rendszeresítették.

Az első megoldások a Gazdasági és Közlekedési Minisztérium által kiírt GVOP-3.1.1-2004-05-0098/3.0 pályázati támogatásával, a Gamma Zrt. és a HM Technológiai Hivatal konzorciuma által, közös fejlesztésben valósultak meg. A létrejött termék a hordozható és könnyen telepíthető sugárkapucsalád első eleme, a BNS-94M mobil sugárkapu volt. Az eszközt hamarosan követte a BNS-94F jármüfedélzeti mobil sugárkapu, lehetővé téve a feltűnés nélküli sugárfelderítést, valamint légi járművek sugárszennyezettségének ellenőrzését. A 9. ábra bevetés közben ábrázolja a mobil és jármúfedélzeti sugárkapukat.

A berendezést a terrorizmus elleni harc egyik eszközeként, személyek ellen alkalmazni kívánt izotópok vagy „piszkos bombák" észlelésére, felderítésére is alkalmazzák. Megjelentek a táskába építhető változatok is, amelyekkel megelőzhető, hogy egy különösen fontos személy közelében lassan, de biztosan ölő sugárzó izotópot helyezhessenek el.

A mobil eszközök újabb felhasználási területét jelentették az áruszállító cégek és a posták, ahol a küldemények ellenőrzésénél jelentek meg az addigra már széles körben használt fix telepítésű rendszereket egészítették ki. Eltérő felhasználási céllal születtek meg a 10. ábrán látható mobil sugárkapuk.

9. ábra. Mobil sugárkapu és jármúfedélzeti sugárkapuk [3]

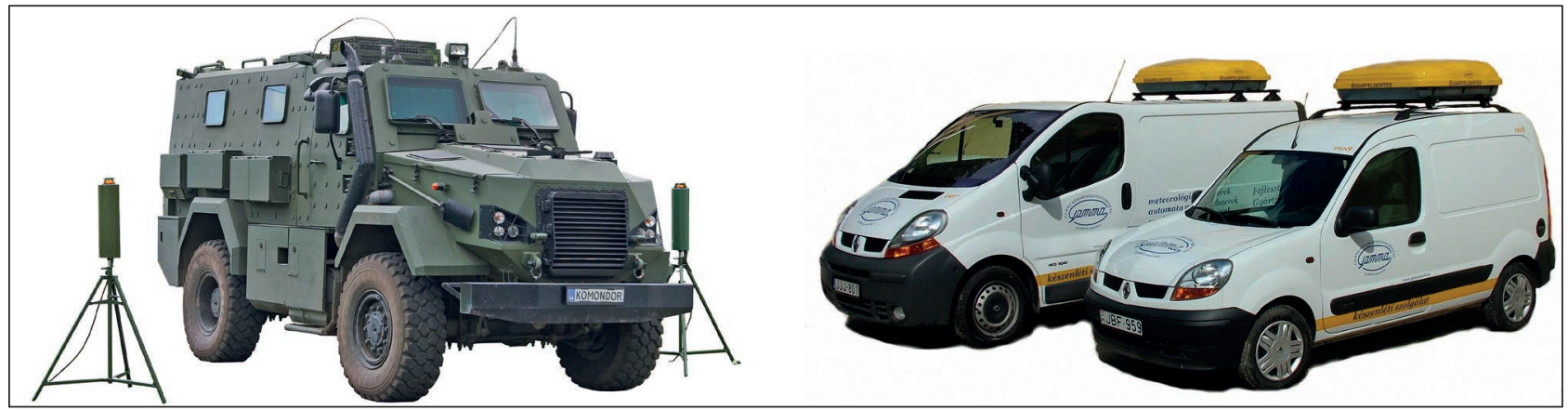




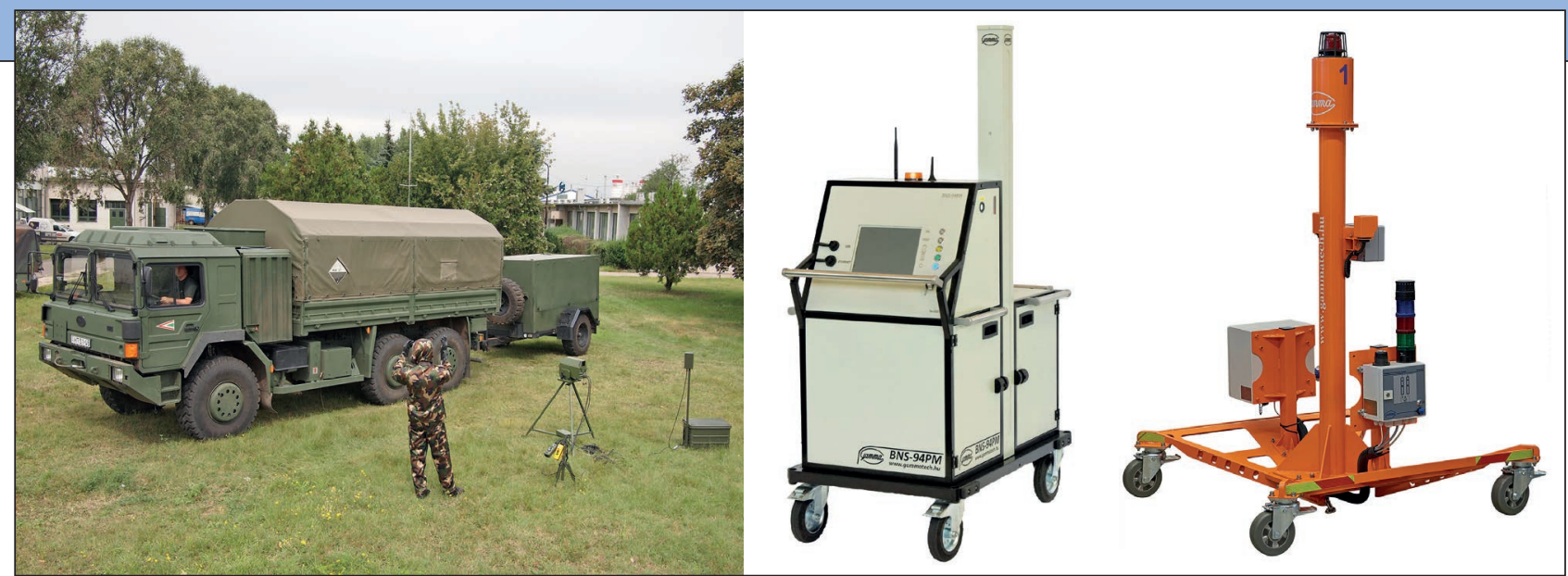

10. ábra. Mobil sugárkapuk [3]
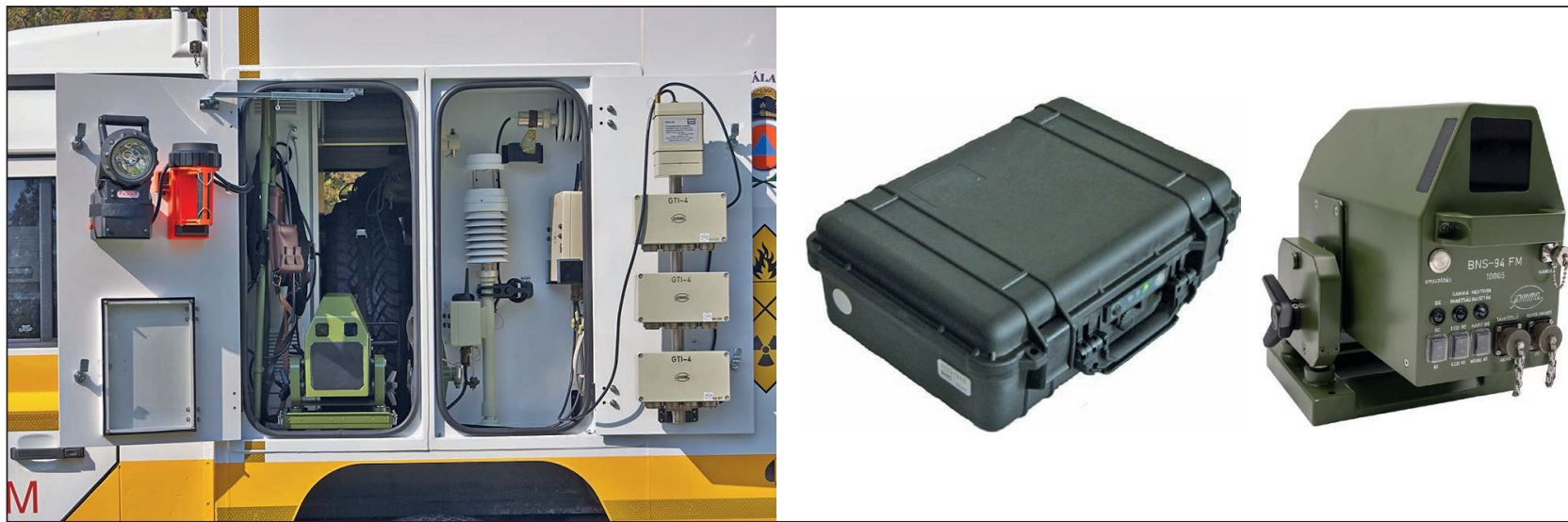

11. ábra. Jármúfedélzeti és táskába integrált sugárkapuk [3]

2009-ben sugárkapuk földön és levegőben egyaránt müködtek, a Nemzeti Fejlesztési és Gazdasági Minisztérium által kiírt, „Védelmi és biztonsági ipar versenyképessége” (VBI) pályázat eredményeként létrejött a folyami szállítási útvonalak illegális forgalmának sugárfelderítésére szolgáló eszköz. Az elkészült BNS-94FM detektornak igen nagy hatósugarú az érzékenysége, ami lehetővé teszi nagy méretű uszályok rakományának az ellenőrzését is. A detektor kombinált, gammaés neutronsugárzás érzékelésére egyaránt alkalmas.

Sok esetben a szennyezőanyag csak egy pontforrást jelent, amelynek a nagy mennyiségú hulladékban vagy más anyagban történő kimutatása nem egyszerű feladat. Erre a feladatra olyan sugárforrás-kereső műszer használata javasolt, amely képes lehet a megtalált forrást azonosítani is. Ma már elérhetőek sugárkapu funkciókkal rendelkező kézi izotópazonosító berendezések, amelyek lehetővé teszik a szállítmány helyszíni gyors minősítését.

Ezeknek egy példánya látható a 12. ábrán.

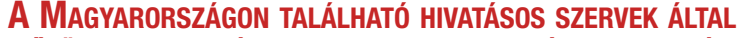 MÜKÖDTETETT SUGÁRKAPU-RENDSZEREK TOVÁBBFEJLESZTÉSI LEHETŐSÉGEI}

Az első rendszerek több mint 25 éve jelentek meg hazánkban, és többségük azóta megszakítás nélkül, folyamatosan működik. Ezért érdemes a sugárkapu-rendszerek továbbfejlesztésén gondolkodni.

A sugárkapuk technikai korszerűsítésének első lépése a detektorok szoftverének, elektronikájának frissítése lehet. A legkorábban üzembe helyezett analóg detektorok cseréje digitális mérőfejekre, ami további 25 évre biztosítaná a rendszer gazdaságos üzemeltethetőségét, csere alkatrészellátottságát.

Jelenleg a határokon működő sugárkapuk olyan technológiával rendelkeznek, amely képes a gamma- és a neutronsugárzás detektálására, azonban nem képes szétválasztani a gamma- és a neutronsugárzásból adódó riasztásokat. Ez a funkcionalitás határellenőrzéskor vagy a közúti mobil ellenőrzésekor rendkívül hasznos, hiszen a neutronsugárzás utalhat nukleáris anyag jelenlétére is. A legújabb fejlesztések eredményeként, ma már létezik olyan megoldás, amely lehetővé teszi a különböző sugárzástípusok megkülönböztetését.

$A z$ izotópazonosítási képesség a sugárzásmérés terén egyre gyakoribb felhasználói igény, a funkció elterjedése várható a sugárkapuk terén is. $A$ határátkelőhelyeken tele-

12. ábra. Sugárforrás-kereső és izotópazonosító múszer [3]

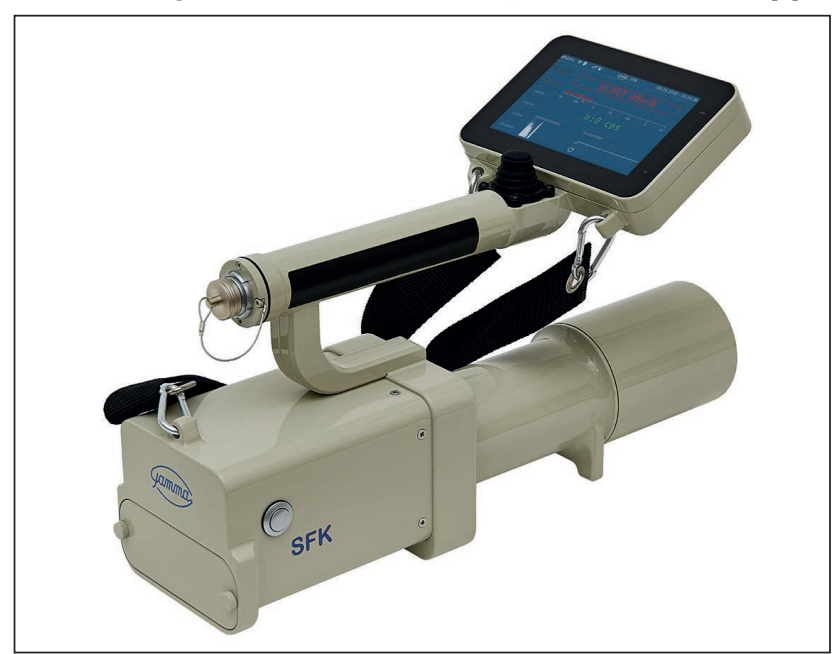


1. táblázat. A Gamma Zrt. által fejlesztett BNS-94 sugárkapucsalád föbb változatai [3]

\begin{tabular}{|c|c|c|c|c|}
\hline Alaptípusok & Mért sugárzás & $\begin{array}{l}\text { Alkalmazás helye, } \\
\text { vagy ellenőrzött } \\
\text { személy/jármú }\end{array}$ & $\begin{array}{l}\text { Telepítés } \\
\text { módja }\end{array}$ & Jellemzők \\
\hline BNS-94 & gamma, neutron & közút, vasút & fix & 2x1 db vízszintesen beépített detektor. \\
\hline BNS-94H & gamma & közút, vasút & fix & 2x1 db függőlegesen beépített detektor. \\
\hline BNS-94H+ & gamma & közút, vasút & fix, mobil & $\begin{array}{l}2 \times 1 \text { db függőlegesen beépített, nagy } \\
\text { érzékenységű detektor. }\end{array}$ \\
\hline BNS-94ZG & gamma & közút, vasút & fix & $\begin{array}{l}2 \times 1 \text { vagy } 2 \times 2 \text { db függőlegesen beépített, nagy } \\
\text { érzékenységű detektor. }\end{array}$ \\
\hline BNS-94PS & gamma & $\begin{array}{l}\text { személyek, } \\
\text { csomagok }\end{array}$ & fix, mobil & $\begin{array}{l}\text { Kordonoszlopba épített. } \\
\text { Egy detektoregységbe } 1 \mathrm{db} \text { függőlegesen } \\
\text { beépített detektor. }\end{array}$ \\
\hline BNS-94P/L & gamma, neutron & $\begin{array}{l}\text { személyek, } \\
\text { csomagok }\end{array}$ & fix & $\begin{array}{l}\text { Átjárók vagy szálítószalagok fölé, mellé } \\
\text { telepíthető. } 2 \times 1 \text { vagy } 2 \times 2 \text { db függőlegesen, vagy } \\
\text { vízszintesen is elhelyezhető detektor. }\end{array}$ \\
\hline BNS-94PM & béta, gamma & $\begin{array}{l}\text { személyek, } \\
\text { csomagok }\end{array}$ & mobil & $\begin{array}{l}\text { Gördíthető, } 2 \text { db függőlegesen beépített } \\
\text { detektort tartalmaz. }\end{array}$ \\
\hline BNS-94PHK & béta, gamma & személyek & fix & $\begin{array}{l}\text { Beépített kéz- és lábszennyezettség-mérő. } \\
8 \text { db GM csővel szerelt, opcionálisan } 2 \text { db } \\
\text { szcintillációs detektorral ruhaszennyezettség- } \\
\text { mérő. }\end{array}$ \\
\hline BNS-94FM & gamma, neutron & közút, személyek & mobil & $\begin{array}{l}\text { Járművekre szerelhető, mobil, állvánnyal. } \\
1 \text { db vízszintesen beépített nagy érzékenységű } \\
\text { detektorból álló rendszer. }\end{array}$ \\
\hline BNS-94M & gamma & $\begin{array}{l}\text { közút, vasút, } \\
\text { személyek }\end{array}$ & fix & $\begin{array}{l}\text { Mobil állványra szerelt, detektoregységenként } \\
1 \text { db detektorra szerelt, beépített riasztóegység- } \\
\text { gel és akkumulátorral rendelkező rendszer. }\end{array}$ \\
\hline BNS-94V & gamma & közút, vasút & fix & 2x1 db nagy méretű plasztik detektor. \\
\hline BNS-94B & gamma, neutron & $\begin{array}{l}\text { személyek, } \\
\text { csomagok }\end{array}$ & hordozható & $\begin{array}{l}\text { Kézipoggyász méretű, ad hoc rejtett } \\
\text { ellenőrzőpontként alkalmazható. } 1 \text { db kollimált } \\
\text { detektoregységből álló rendszer. }\end{array}$ \\
\hline
\end{tabular}

pített, vagy a speciális járművekbe épített intelligens mérőfejekkel szerelt sugárkapuk alkalmassá tehetők izotóp azonosítására.

A sugárkapu-rendszerekhez video-megfigyelő rendszer illeszthető, amelynek segítségével a riasztásokhoz képi információt is rögzíthetnek és tárolhatnak.

A sugárkapuk alapkiépítésben csak helyi riasztással, kijelzéssel rendelkeznek. Ahhoz, hogy nagy számban, kiterjedt területen, összehangoltan lehessen a rendszert üzemeltetni, hasznos a távmenedzsment funkció.

A Magyarországon működő Országos Sugárfigyelő, Jelző és Ellenőrző Rendszer (továbbiakban: OSJER) folyamatosan méri a háttérsugárzás-értékeket. A rendszert folyamatosan bővítik, de határainkon nincsenek az OSJER-hez tartozó érzékelők, ezért az esetlegesen a szomszédos országokból érkező sugárszennyeződéseket csak késve, jóval határainkon belül detektálhatják. A sugárkapuk bővíthetők az OSJERrendszerben is használt detektorokkal is [10].

\section{ÖSSZEFOGLALÁs}

A sugárkapuk működését több tényező is befolyásolja, amelyek sok esetben eldöntik, hogy az képes-e a belépő rejtett sugárforrás észlelésére vagy sem.
Az első tényező a detektor mérete. Ezen a téren a szcintillációs detektorok a legmegfelelőbbek, de ezek közül is, a feladattól függően különböző méretűeket lehet alkalmazni.

A második tényező a távolság. Minél közelebb van a detektor a vizsgálandó céltárgyhoz/személyhez, az abból származó sugárzás annál nagyobb hányada éri el a detektort. Úgy kell elhelyezni detektoregységeket, hogy azok minél közelebb legyenek a közlekedési folyosóhoz/úthoz, de még ne akadályozzák a forgalmat.

A harmadik tényező a vizsgálati magasság. A detektoregységeknek adott magasságon eltérő érzékenysége lehet. A detektorkollimátoron kimart nyílás határozza meg a vizsgálati térszöget, ami tipikusan kúp alakú. A vizsgálati magasságtartomány egy személygépjármű esetén lényegesen kisebb, mint egy teherautó, vonat vagy busz esetében. A detektor telepítési magasságának megfelelő megválasztása, vagy több detektor egymás fölé történő telepítése javítja a céltárgy/személy ellenőrzésének hatékonyságát.

A negyedik tényező a sugárkapuk alkalmazásakor az áthaladás sebessége. Minél gyorsabban halad át a vizsgálandó személy, tárgy vagy jármű a kapun, annál kevesebb idő áll rendelkezésre a mérés végrehajtására és a döntés meghozatalára, ezért a sugárkapuk elhelyezésekor korlátozni kell az áthaladás sebességét. A legtöbb sugárkapurendszer esetében az optimális áthaladási sebesség $15 \mathrm{~km} / \mathrm{h}$ alatt van. 
A fix telepítésű sugárkapukon túl léteznek már mobil, jármúbe szerelhető, vagy akár kézben hordozható változatok is. A kézi változatokat akkor érdemes alkalmazni, amikor a vizsgált céltárgy/személy nem tud, nem képes a sugárkapun áthaladni. A kézi sugárkapuk például egy ideiglenes mentesítő rendszer hatékonyságának ellenőrzésére is használhatók.

A sugárkapuk képességei jelentős mértékben bővültek az elmúlt években is, a Gamma Zrt.-nél a fejlesztések ezen a területen is folyamatosak. A Széchenyi 2020 program (VEKOP-2.1.1-15-2016-00023) támogatásával megvalósult új generációs multifunkciós automata mérő és adatgyűjtő rendszercsalád fejlesztése során növekedett a sugárkapu-rendszerek érzékenysége, megbízhatósága, kevesebb a hibalehetőség, valamint egyszerübbé vált a rendszerek használata.

\section{RODALOMJEGYZÉK}

[1] Pesznyák Csilla és Sáfrány Géza. Sugárbiológia (Budapest: Typotex, 2016), p. 16.

[2] Solymosi József, Hanka László és Vincze Árpád. „A nukleáris terrorizmus mint potenciális fenyegetettség napjainkban," Hadmérnök 2, 4. sz. (2007 december): p. 6, http://hadmernok.hu/ archivum/2007/4/2007_4_hanka.pdf;

[3] „Gammatech.hu”, GAMMA Zrt., 2019. [Online]. Available: www.gammatech.hu;

[4] „European Agreement concerning the International Carriage of Dangerous Goods by Road," United Nations: 2016, Letöltve: 2019.10.30,
http://www.unece.org/fileadmin/DAM/trans/danger/ publi/adr/adr2017/ADR2017E_web.pdf;

[5] D. C. Stromswold, S. Edward R., J. E. Schweppe, J. H. E. Ely, B. D. Milbrath, K. Richard T. és G. Bruce D. „Comparison of Plastic and $\mathrm{Nal}(\mathrm{TI})$ Scintillators," Nuclear Science Symposium Conference, 2003.;

[6] Bäumler Ede, Deme Sándor és Vincze Árpád „A hazai sugárvédelmi müszergyártás múltja és jelene,” Fizikai Szemle 54, 7. sz. (2004): p. 220, http://fizikaiszemle.hu/old/archivum/fsz0407/ baumler0407.html;

[7] A. L. Juan. „Informe respuesta a la pregunta formulada por D. Juan Antonio López de Uralde, representante de la asociación Greenpeace sobre el accidente de Acerinox de 1998," Letöltve: 2020.03.19, https://web.archive.org/ web/20110720140125/http:/www.csn.es/descarga/ GreenpeaceRespAcerinox.pdf;

[8] Kiss Ervin. „Környezetünk nukleáris veszélyeztetettsége”. Diplomamunka, Soproni Egyetem, Erdészeti Géptani Tanszék, 1999.;

[9] Magyarország Kormánya, 490/2015. (XII. 30.) Korm. rendelet a hiányzó, a talált, valamint a lefoglalt nukleáris és más radioaktív anyagokkal kapcsolatos bejelentésekröl és intézkedésekröl Letöltve: 2020.03.19., https://net.jogtar.hu/jogszabaly?docid=a1500490.kor;

[10] Kátai-Urbán Lajos, Vass Gyula és Zellei Gábor. „25 éve működik hazánkban a radiológiai távmérő hálózat" Hadtudomány 28. évf., 2. sz. (2018): p. 145 https://doi.org/10.17047/HADTUD.2018.28.2.140.

\section{Kovács László}

\section{Kiberbiztonság és -stratégia}

A kibertér mindennapjaink meghatározó dimenziójává vált. Életünk és társadalmi környezetünk minden rétegére hatással van, legyen szó gazdaságról, politikáról, kultúráról vagy akár a magánéletünk egyes elemeiről. A kibertér biztonsága valamennyi ország elemi érdeke. Fontossága ma már nem kérdőjelezhető meg, a megjelenő kihívásokra, veszélyforrásokra stratégiai szintű válaszokat kell adni. Egyre sürgetőbb, hogy az öszszes ország gondolkodjon és gondoskodjon a kibertér biztonságáról, hiszen a technika fejlődésének üteme a társadalom számára nemcsak pozitív, hanem negatív tényezőket is jelent. Prof. dr. Kovács László kötete a kiberbiztonság legfontosabb összefüggéseire, valamint azok stratégiai dokumentumokban történő megjelenésére fókuszál. Bemutatja továbbá a Magyarországhoz hasonló méretű országok kiberbiztonsági stratégiáját és politikáját, felvázolja az Európai Unió tagországainak kiberbiztonságról alkotott stratégiai elképzeléseit, és ismerteti az Unió és a NATO ide vonatkozó irányelveit, valamint megismerhetjük azok rövid elemzését is. A könyv a kiberbiztonság legfontosabb össze-

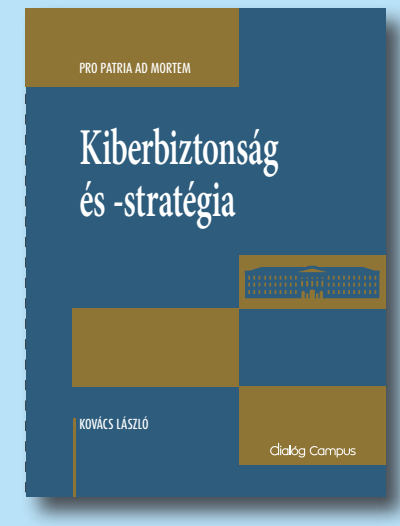
tevőit és a kiberhadviselés elméletét is tárgyalja. Az egyes országokban ugyanis a biztonság mellett megjelenik a kibertér katonai, illetve politikai célokra történő alkalmazásának igénye, amelyet a szerző néhány valós esettel illusztrál az olvasók számára. Ennek során az érdeklődő bepillantást nyerhet az Amerikai Egyesült Államok, Kína és Oroszország kiberhadviselésébe, azaz körvonalazódhat számára, hogy a nagyhatalmak milyen tevékenységet folytatnak a kibertérben. A könyv önálló fejezetben foglalja össze a korábban bemutatott országok kiberbiztonsági stratégiainak legfontosabb elemeit. A szerző dandártábornok, a Magyar Honvédség haderőnemi szemlélője, egyetemi tanár. A rendkívül adatgazdag kötetet - amely a Pro Patria ad Mortem sorozatban jelent meg - a rövidítések, az illusztrációk, a táblázatok jegyzéke, valamint bőséges irodalomjegyzék zárja. A kötetet elsősorban a kiberbiztonság iránt érdeklődő olvasóknak ajánljuk, különös tekintettel arra, hogy a NATO a közelmúltban a kiberteret is műveleti térré nyilvánította.

A kötet a Dialóg Campus Kiadó által 2018-ban „A jó kormányzást megalapozó közszolgálatfejlesztés” elnevezésú kiemelt projekt keretében jelent meg. A kemény borítós könyv terjedelme $\mathbf{3 5 0}$ oldal, pdf változata letölthető: https://akfi-dl.uni-nke.hu/pdf_kiadvanyok/web_PDF_Kiberbiztonsag_es_strategia.pdf oldalról. (W. T.) 